\title{
Aplikasi Cendawan Endofit terhadap Perkembangan Populasi Nematoda Radopholus similis pada Pisang Barangan
}

\author{
Application Method of Endophytic Fungi on \\ Radopholus similis Population on Banana Barangan Cultivar
}

\author{
Lisnawita $^{1^{*}}$, Ahmad Rafiqi Tantawi ${ }^{2}$, Mukhtar Iskandar Pinem ${ }^{1}$ \\ ${ }^{1}$ Universitas Sumatera Utara, Medan 20155 \\ ${ }^{2}$ Universitas Medan Area, Medan 20121
}

\begin{abstract}
ABSTRAK
Radopholus similis adalah salah satu faktor pembatas utama produksi pisang di dunia termasuk Indonesia dan petani selalu mengandalkan nematisida untuk mengelola kehilangan hasil. Penggunaan cendawan endofit merupakan salah satu metode yang dapat mengurangi kebutuhan nematisida, tetapi sedikit sekali informasi tentang metode aplikasi cendawan endofit yang efektif untuk mengendalikan $R$. similis. Penelitian ini bertujuan untuk mendapatkan metode aplikasi cendawan endofit yang efektif untuk menekan populasi $R$. similis pada tanaman pisang. Lima belas cendawan endofit yang diisolasi dari akar dan bonggol pisang dari beberapa pertanaman pisang di Sumatera Utara diaplikasikan pada pisang Barangan dengan metode tabur dan rendam. Isolat cendawan endofit terdiri atas 11 isolat Fusarium sp. (2BSTMHMM, 3ASTMHP, 5ASP, 1ASU, 4BSP, 4BJP, 5BKJP, 4BSU, 1BJP, 2 BSP, dan 4BKJP) dan 4 isolat Trichoderma sp. (2BSTMHP, 4BSTMHP, 2BSPH, dan 2BSTMHH). Hasil penelitian menunjukan bahwa 15 isolat cendawan endofit tersebut mampu menekan populasi $R$. similis dan memiliki potensi meningkatkan pertumbuhan tanaman.
\end{abstract}

Kata kunci: Fusarium sp., metode aplikasi, pisang Barangan, Radopholus similis, Trichoderma sp.

\begin{abstract}
Radopholus similis is a major constraint to banana production in the world including Indonesia and growers have relied on nematicides to manage yield losses. The use of endophytic fungi is one method that may reduce the need for nematicides, however little is known on the effective application method of endophytic fungi to control $R$. similis. The aim of this research was to find out an effective application method of endophytic fungi to reduce R.similis population on banana. Fifteen isolates of endophytic fungi originated from banana corm and root collected from banana plantation in North Sumatera were applied to Barangan cultivar by sowing and deeping methods. The isolates was contained of 11 isolates of Fusarium sp. (2BSTMHMM, 3ASTMHP, 5ASP, 1ASU, 4BSP, 4BJP, 5BKJP, 4BSU, 1BJP, 2 BSP, and 4BKJP) and 4 isolates of Trichoderma sp. (2BSTMHP, 4BSTMHP, 2BSPH, and 2BSTMHH). All of these endophytic fungi were able to suppress the population of $R$. similis and they had potential to promote plant growth.
\end{abstract}

Key words: application method, banana Barangan cultivar, Fusarium sp., Radopholus similis, Trichoderma sp.

*Alamat penulis korespondensi: Program studi Agroekoteknologi, Fakultas Pertanian, Universitas Sumatera Utara, Jalan Dr Mansyur No 9, Medan 20155

Tel: 061-061-8223570,061-8213236, Faks: 061-8211924, Surel: itamuis@yahoo.com 


\section{PENDAHULUAN}

Radopholus similis merupakan nematoda endoparasit migratori yang tersebar luas di daerah pertanaman pisang di dunia. Nematoda masuk ke dalam akar, berpindah-pindah di dalam jaringan, aktif makan dan berkembang biak di dalam akar. Akar tanaman pisang yang terserang menunjukkan gejala bintik-bintik cokelat kemerahan memanjang sejajar dengan silender pusat pada jaringan korteksnya. Gejala ini akan berubah menjadi luka memanjang berwarna hitam.

Umumnya petani menggunakan nematisida berbahan aktif organoposfat dan karbamat untuk mengendalikan serangan nematoda. Penggunaan nematisida kimia berdampak pada keanekaragaman hayati dan proses biologi tanah (Eisenhauer et al. 2010). Selain itu aplikasi nematisida memberikan pengaruh negatif terhadap kesehatan lingkungan dan membutuhkan biaya yang cukup besar. Oleh karena itu, pengendalian nematoda parasit tumbuhan pada tanaman pisang yang ramah lingkungan seperti dengan pengendalian biologi menggunakan cendawan endofit perlu dicari.

Selain sebagai agens hayati, cendawan endofit seperti Trichoderma dan Gliocladium diketahui juga mampu meningkatkan pertumbuhan tanaman. Pemanfaatan cendawan endofit untuk pengendalian patogen telah banyak dilaporkan, tetapi belum ada informasi cara aplikasi yang tepat dari cendawan tersebut untuk mengendalikan $R$. similis. Oleh karena itu, penelitian ini bertujuan menentukan metode aplikasi cendawan endofit yang efektif untuk menekan populasi nematoda $R$. similis pada tanaman pisang.

\section{BAHAN DAN METODE}

\section{Perbanyakan}

Nematoda $R$. similis diisolasi dari akar tanaman pisang dari lapangan, dan diperbanyak pada medium wortel. Wortel segar dibersihkan dengan natrium hipoklorit 5.25\%, kemudian dicuci dengan air mengalir. Setelah itu wortel dipotong-potong setebal $3 \mathrm{~cm}$ dan direndam dalam natrium hipoklorit 1.5\% selama 15 menit, selanjutnya direndam dan dibilas dengan akuades steril sebanyak 2-3 kali. Potongan wortel ditempatkan pada botol kultur. Nematoda $R$. similis yang telah diisolasi, disterilkan dengan larutan $\mathrm{HgCl}_{2}$ $0.01 \%$ dan streptomisin sulfat $0.1 \%$ selama 30 detik dan dibilas dengan air steril. Sebanyak 10-15 nematoda yang terdiri atas jantan, betina, dan juvenil diambil menggunakan pipet diinokulasikan pada potongan wortel. Biakan diinkubasi pada suhu ruang selama $2-3$ bulan dan akan digunakan sebagai sumber inokulum.

\section{Perbanyakan Pisang}

Tanaman pisang kultivar Barangan hasil perbanyakan dengan teknik kultur jaringan digunakan dalam penelitian ini. Tanaman diperbanyak di medium pertumbuhan Murashige dan Skoog (MS) seperti yang didiskripsikan oleh Vuylsteke (1998). Untuk mendapatkan tanaman pisang dalam jumlah yang banyak dilakukan subkultur yang berulang pada medium yang sama.

\section{Perbanyakan Cendawan Endofit}

Biakan murni 15 isolat cendawan endofit terdiri atas 11 isolat Fusarium sp. (2BSTMHMM, 3ASTMHP, 5ASP, 1ASU, 4BSP, 4BJP, 5BKJP, 4BSU, 1BJP, 2 BSP, dan 4BKJP) dan 4 isolat Trichoderma sp. (2BSTMHP, 4BSTMHP, 2BSPH, dan 2BSTMHH) diperoleh dari berbagai lokasi pertanaman pisang di Sumatera Utara yang merupakan koleksi Laboratorium Penyakit Tumbuhan, Fakultas Pertanian USU. Koloni cendawan yang telah diremajakan pada medium PDA di dalam cawan petri berumur 5 hari diperbanyak dengan menggunakan medium jagung giling. Setiap plastik berisi 50 gjagung giling sterilyang diinokulasi dengan cendawan endofit uji. Biakan disimpan pada suhu ruang sampai seluruh permukaan jagung ditutupi dengan miselium dan siap digunakan. Konsentrasi spora cendawan endofit dihitung sebelum digunakan, yaitu dengan cara mengambil masing-masing $1 \mathrm{~g}$ substrat yang ditumbuhi cendawan endofit lalu dimasukkan ke dalam $9 \mathrm{~mL}$ akuades steril kemudian 
dihomogenkan dan disaring. Sebanyak $1 \mathrm{~mL}$ suspensi dihitung konsentrasi sporanya menggunakan haemositometer dan suspensi ini digunakan untuk inokulasi dengan metode sebar.

Sebelum dilakukan perendaman terlebih dahulu dibuat suspensi ke 15 isolat cendawan endofit yang digunakan. Koloni cendawan endofit yang dibiakkan pada medium PDA umur 5 hari dimasukkan ke dalam gelas beaker yang berisi $100 \mathrm{~mL}$ akuades steril, kemudian dihomogenkan dan disaring. Suspensi hasil saringan diambil sebanyak $1 \mathrm{~mL}$ dengan mikropipet, kemudian dihitung konsentrasi sporanya menggunakan haemositometer dan suspensi ini digunakan untuk inokulasi dengan metode sebar dan rendam.

\section{Aplikasi Cendawan Endofit}

Metode sebar dilakukan pada planlet tanaman pisang yang akan diaklimatisasi. Planlet dari botol kultur, akarnya dicuci dengan air mengalir dan dibersihkan dari medium tumbuhnya, kemudian ditanam dalam pot yang berisi tanah dan pasir steril $(1: 1 / \mathrm{v}: \mathrm{v})$ sebanyak $2 \mathrm{~kg}$ pot $^{-1}$. Sebanyak $50 \mathrm{~g}$ biakan cendawan endofit dalam medium jagung giling $\left( \pm 10^{6}\right)$ disebarkan di sekeliling leher akar. Sebagai kontrol digunakan jagung giling steril tanpa cendawan endofit. Planlet yang sudah ditanam diinkubasi dalam ruangan plastik selama 4 minggu.

Tanaman pisang yang digunakan merupakan planlet pada medium MS yang berumur 2 bulan. Planlet tanaman pisang yang berumur 2 bulan dikeluarkan dari botol kultur, akarnya dicuci dengan air mengalir agar bersih dari medium tumbuh. Selanjutnya akar direndam di dalam $100 \mathrm{~mL}$ suspensi cendawan endofit $\left(10^{6}\right)$ selama 60 menit dan planlet ditanam dalam pot yang berisi tanah dan pasir steril $(1: 1 / \mathrm{v}: \mathrm{v})$ sebanyak $2 \mathrm{~kg}$ pot $^{-1}$. Sebagai kontrol digunakan air steril. Planlet yang sudah ditanam diinkubasikan dalam ruangan ditutup dengan plastik selama 4 minggu.

\section{Inokulasi Nematoda}

Empat minggu setelah aplikasi cendawan endofit planlet diinokulasi dengan 500 ekor
R. similis (Nancy et al. 2009). Inokulasi dilakukan dengan menuangkan suspensi 100 ekor per hari di sekeliling tanaman pada kedalaman $1 \mathrm{~cm}$ selama 5 hari berturut-turut.

\section{Rancangan Percobaan}

Percobaan ini disusun menggunakan rancangan acak lengkap faktorial dengan 3 ulangan. Faktor pertama adalah isolat cendawan endofit yang terdiri atas 11 isolat Fusarium sp. (2BSTMHMM, 3ASTMHP, 5ASP, 1ASU, 4BSP, 4BJP, 5BKJP, 4BSU, 1BJP, 2 BSP, dan 4BKJP) dan 4 isolat Trichoderma sp. (2BSTMHP, 4BSTMHP, 2BSPH, dan 2BSTMHH) dan faktor kedua adalah metode aplikasi yang terdiri atas metode sebar dan metode rendam.

Enam minggu setelah inokulasi nematoda, tanaman dibongkar, dicuci, dan dikeringanginkan. Peubah yang diamati ialah bobot basah akar, tinggi tanaman, dan jumlah $R$. similis di dalam akar dan tanah. Jumlah nematoda dihitung menggunakan metode modifikasi corong Baermann. Uji perlakuan terhadap peubah yang diamati dianalisis dengan uji Duncan New Multiple Range Test pada taraf $5 \%$.

\section{HASIL}

\section{Populasi Radopholus similis}

Pengamatan akhir $R$. similis yang diaplikasikan dengan metode sebar dan metode rendam secara nyata mampu menekan populasi $R$. similis (Tabel 1).

\section{Tinggi Tanaman dan Bobot Basah Akar}

Pemberian cendawan endofit dengan metode sebar maupun metode rendam memberikan respons yang cukup baik untuk tinggi tanaman dan bobot basah akar. Pertambahan tinggi tanaman dan bobot basah akar bervariasi bergantung pada isolat cendawan endofit yang digunakan. Sebaliknya, pada tanaman yang hanya diinokulasi nematoda terlihat pertumbuhan tanaman tertekan (Tabel 2). 
Tabel 1 Pengaruh cendawan endofit terhadap populasi Radopholus similis pada planlet tanaman pisang umur empat minggu

\begin{tabular}{lrcc}
\hline \multirow{2}{*}{ Perlakuan } & \multicolumn{3}{c}{ Populasi nematoda* } \\
\cline { 2 - 4 } K1 (Tanpa nematoda) & Metode sebar & Metode rendam \\
K 2 (Hanya nematoda) & $0.01 \mathrm{i}$ & $0.0 \mathrm{i}$ \\
Fusarium sp. (2BSTMHMM) & $123.5 \mathrm{a}$ & $121.8 \mathrm{a}$ \\
Fusarium sp. (3ASTMHP) & $29.2 \mathrm{~g}$ & $24.6 \mathrm{gh}$ \\
Fusarium sp. (5ASP) & $49.2 \mathrm{de}$ & $23.6 \mathrm{gh}$ \\
Fusarium sp. (1ASU) & $47.7 \mathrm{de}$ & $38.0 \mathrm{f}$ \\
Fusarium sp. (4BSP) & $72.5 \mathrm{c}$ & $56.2 \mathrm{~d}$ \\
Trichoderma sp. (2BSTMHP) & $68.7 \mathrm{c}$ & $35.3 \mathrm{fg}$ \\
Trichoderma sp. (4BSTMHP) & $44.4 \mathrm{e}$ & $51.2 \mathrm{~d}$ \\
Fusarium sp. (4BJP) & $88.5 \mathrm{bc}$ & $50.2 \mathrm{~d}$ \\
Fusarium sp. (5BKJP) & $99.3 \mathrm{~b}$ & $96.0 \mathrm{bc}$ \\
Fusarium sp. (4BSU) & $74.6 \mathrm{c}$ & $39.7 \mathrm{f}$ \\
Fusarium sp. (1BJP) & $44.6 \mathrm{e}$ & $57.9 \mathrm{~d}$ \\
Fusarium sp. (2BSP) & $100.8 \mathrm{~b}$ & $60.2 \mathrm{c}$ \\
Fusarium sp. (4BKJP) & $90.4 \mathrm{bc}$ & $36.8 \mathrm{f}$ \\
Trichoderma sp. (2BSPH) & $95.5 \mathrm{bc}$ & $55.5 \mathrm{~d}$ \\
Trichoderma sp. (2BSTMHH) & $90.4 \mathrm{bc}$ & $73.4 \mathrm{c}$ \\
& $95.5 \mathrm{bc}$ & $62.6 \mathrm{c}$ \\
\hline Angang
\end{tabular}

*Angka yang diikuti dengan huruf yang sama pada kolom yang sama tidak berbeda nyata pada taraf $5 \%$ berdasarkan uji DMRT

Tabel 2 Pengaruh cendawan endofit terhadap tinggi dan bobot basah akar planlet tanaman pisang umur 4 minggu

\begin{tabular}{|c|c|c|c|c|}
\hline \multirow{2}{*}{ Perlakuan } & \multicolumn{2}{|c|}{ Tinggi tanaman* $(\mathrm{cm})$} & \multicolumn{2}{|c|}{ Berat basah akar* (g) } \\
\hline & Metode sebar & Metode rendam & Metode sebar & Metode rendam \\
\hline K1 (Tanpa nematoda) & $13.37 \mathrm{~h}$ & $13.94 \mathrm{~h}$ & $2.48 \mathrm{c}$ & $2.90 \mathrm{c}$ \\
\hline K 2 (Hanya nematoda) & $12.71 \mathrm{~h}$ & $12.55 \mathrm{~h}$ & $0.91 \mathrm{~d}$ & $0.96 \mathrm{~d}$ \\
\hline Fusarium sp. (2BSTMHMM) & $19.93 \mathrm{~d}$ & $15.21 \mathrm{fg}$ & $4.84 \mathrm{a}$ & $3.27 \mathrm{~b}$ \\
\hline Fusarium sp. (3ASTMHP) & $21.00 \mathrm{~cd}$ & $14.71 \mathrm{~g}$ & $4.43 \mathrm{~b}$ & $3.22 \mathrm{~b}$ \\
\hline Fusarium sp. (5ASP) & $20.40 \mathrm{~d}$ & $15.17 \mathrm{~g}$ & $4.58 \mathrm{~b}$ & $3.35 \mathrm{~b}$ \\
\hline Fusarium sp. (1ASU) & $20.61 \mathrm{~cd}$ & $14.61 \mathrm{~g}$ & $4.25 \mathrm{~b}$ & $3.08 \mathrm{~b}$ \\
\hline Fusarium sp. (4BSP) & $19.38 \mathrm{~d}$ & $14.21 \mathrm{~g}$ & $4.80 \mathrm{~b}$ & $3.27 \mathrm{~b}$ \\
\hline Trichoderma sp. (2BSTMHP) & $25.37 \mathrm{a}$ & $14.71 \mathrm{~g}$ & $4.07 \mathrm{~b}$ & $3.11 \mathrm{~b}$ \\
\hline Trichoderma sp. (4BSTMHP) & $19.71 \mathrm{~d}$ & $20.04 \mathrm{~d}$ & $3.62 \mathrm{~b}$ & $3.36 \mathrm{~b}$ \\
\hline Fusarium sp. (4BJP) & $19.04 \mathrm{e}$ & $16.21 \mathrm{f}$ & $4.66 \mathrm{~b}$ & $3.24 \mathrm{~b}$ \\
\hline Fusarium sp. (5BKJP) & $18.37 \mathrm{e}$ & $15.94 \mathrm{f}$ & $4.32 \mathrm{~b}$ & $3.54 \mathrm{~b}$ \\
\hline Fusarium sp. (4BSU) & $22.94 \mathrm{bc}$ & $20.27 \mathrm{~d}$ & $4.72 \mathrm{~b}$ & $3.06 \mathrm{~b}$ \\
\hline Fusarium sp. (1BJP) & $19.79 \mathrm{~d}$ & $24.37 \mathrm{~b}$ & $4.67 \mathrm{~b}$ & $3.45 \mathrm{~b}$ \\
\hline Fusarium sp. (2BSP) & $21.56 \mathrm{c}$ & $17.07 \mathrm{ef}$ & $4.71 \mathrm{~b}$ & $3.60 \mathrm{~b}$ \\
\hline Fusarium sp. (4BKJP) & $19.12 \mathrm{de}$ & $16.27 \mathrm{f}$ & $4.47 \mathrm{~b}$ & $3.26 \mathrm{~b}$ \\
\hline Trichoderma sp. (2BSPH) & $20.21 \mathrm{~d}$ & $22.37 \mathrm{c}$ & $4.59 \mathrm{~b}$ & $3.32 \mathrm{~b}$ \\
\hline Trichoderma sp. (2BSTMHH) & $20.37 \mathrm{~d}$ & $15.94 \mathrm{f}$ & $4.38 \mathrm{~b}$ & $3.40 \mathrm{~b}$ \\
\hline
\end{tabular}

*Angka yang diikuti dengan huruf yang sama pada kolom yang sama tidak berbeda nyata pada taraf $5 \%$ berdasarkan uji DMRT 


\section{PEMBAHASAN}

Nematoda parasit penting pada tanaman pisang, $R$. similis, sudah menyebar luas di pertanaman pisang di Sumatera Utara (Sinaga et al. 2013). Kehadiran nematoda ini selalu berasosiasi dengan patogen tular tanah lainnya seperti Fusarium oxysporum f. sp. cubense sehingga menyebabkan kerusakan tanaman pisang semakin parah. Kurangnya pengetahuan petani tentang nematoda menyebabkan berbagai upaya pengendalian yang dilakukan belum memberikan hasil yang memuaskan. Kehadiran $R$. similis pada tanaman pisang menyebabkan luka nekrotik pada akar. Luka-luka ini menjadi jalan masuk bagi patogen tular tanah lainnya untuk menginfeksi tanaman pisang.

Strategi pengendalian dengan cara menginduksi ketahanan tanaman merupakan salah satu cara alternatif untuk mengendalikan $R$. similis. Penggunaan mikroorganisme nonpatogen seperti cendawan endofit dilaporkan dapat menginduksi ketahanan sistemik tanaman. Berbagai hasil penelitian telah dilaporkan tentang potensi cendawan endofit sebagai agens hayati untuk mengendalikan R. similis (Pocasangre et al. 2000; Niere et al. 2004).

Hasil penelitian ini menunjukkan semua isolat cendawan endofit yang diaplikasikan dengan metode sebar maupun metode rendam secara nyata dapat menurunkan populasi $R$. similis. Kemampuan cendawan endofit dalam menekan populasi nematoda disebabkan karena cendawan endofit menghasilkan senyawa kimia yang bersifat nematisidal dan dapat memicu pertahanan tanaman (Yan et al. 2011). Tan dan Zou (2001) melaporkan senyawa kimia yang dihasilkan oleh cendawan endofit dapat melindungi tanaman dan memainkan peranan yang penting dalam menekan penetrasi nematoda. Senyawa kimia bersifat toksik terhadap nematoda yang dihasilkan oleh cendawan endofit ialah asam rizoctonat dan momomentilsuloklin, ergosterol, dan $3 \beta, 5 \alpha, 6 \beta$-trihidroxiergosta-7.22-dien yang dihasilkan oleh isolat Rhizoctonia sp. Pengujian in vitro menunjukkan adanya mekanisme antibiosis antara cendawan endofit yang digunakan dalam penelitian ini terhadap $R$. similis yang ditunjukkan dengan tingginya mortalitas nematoda yang diberikan cendawan endofit di bandingkan dengan kontrol (Data tidak ditampilkan).

Pengamatan terhadap pertumbuhan tanaman menunjukkan semua isolat cendawan endofit yang digunakan dalam penelitian ini berpotensi memacu pertumbuhan tanaman. Semua cendawan endofit yang diaplikasikan dengan metode sebar dan metode rendam menunjukkan pengaruh yang nyata dalam meningkatkan pertumbuhan tanaman terutama tinggi tanaman dan bobot basah akar dibandingkan dengan yang tidak diberi cendawan endofit. Nassar et al. (2005) melaporkan meningkatnya pertumbuhan tanaman karena pemberian cendawan endofit disebabkan karena cendawan endofit dapat berperan sebagai pemacu pertumbuhan tanaman karena kemampuannya mengeluarkan hormon pertumbuhan yang disebut fitohormon seperti etilen, auxin dan sitokinin. Lebih lanjut Nassar et al. 2005 melaporkan banyak galur Fusarium sp. dan cendawan endofit lainnya menghasilkan fitohormon seperti giberelin dan auksin. Obura (2010) juga melaporkan kemampuan cendawan endofit seperti Trichoderma sp. Fusarium sp., Nigrospora sp., dan Chrysosporium sp. dalam meningkatkan pertumbuhan tanaman tomat.

Bobot basah akar pada semua tanaman yang diberi cendawan endofit secara nyata lebih berat dibandingkan dengan tanaman yang hanya diinokulasi nematoda. Fallas et al. (1995) melaporkan penurunan bobot tajuk dan akar menjadi indikator patogenisitas nematoda dan dapat digunakan untuk mengukur besarnya penekanan yang dilakukan oleh nematoda puru akar.

Menurut Hallmann et al. (1997) aplikasi bakteri endofit dapat dilakukan melalui perlakuan benih, penyiraman ke tanah, injeksi batang, penyemprotan suspensi, dan perendaman akar. Keuntungan dari perlakuan benih, seperti perendaman akar (tanaman kultur jaringan), perendaman bibit, atau introduksi bakteri ke dalam tanah sebelum ditanam merupakan suatu usaha proteksi 
pada awal pertumbuhan. Paparu et al. (2004) melaporkan penggunaan medium padat untuk aplikasi cendawan endofit pada akar tanaman pisang memberikan hasil yang cukup baik, ditandai dengan ukuran bonggol dan akar yang lebih besar dibandingkan dengan penggunaan suspensi.

Secara umum dapat disimpulkan semua cendawan endofit yang digunakan mempunyai potensi sebagai agens hayati untuk menekan populasi $R$. similis dan memacu pertumbuhan tanaman baik diaplikasikan dengan metode sebar maupun metode rendam. Hasil penelitian ini diharapkan dapat menjadi informasi metode aplikasi cendawan endofit efektif yang dapat dilakukan untuk menekan populasi $R$. similis.

\section{UCAPAN TERIMA KASIH}

Penelitian merupakan bagian dari penelitian Hibah Fundamental Tahun 2010 dengan Kontrak 2010 No 2288/H5.1.R/ KEU/2010 tanggal 21 April 2010, penulis mengucapkan terima kasih kepada Direktorat Jenderal Pendidikan Tinggi, Kementerian Pendidikan Nasional.

\section{DAFTAR PUSTAKA}

Eisenhauer N, Ackermann M, Gass S, Klier M, Migunova V, Nitschke N, Ruess L, Sabais ACW, Weisser WW, Scheu S. 2010. Nematicide impacts on nematodes and feedbacks on plant productivity in a plant diversity gradient. Acta Oecol. 36:477-483. DOI: http://dx.doi.org/10.1016/j.actao.20 10.06.004.

Fallas GA, Sarah JL, Fargette M. 1995. Reproduction fitness and pathogenecity of eight Radopholus similis isolates on banana plants (Musa AAA cv. Poyo). Namatropica. 25:135-141.

Hallmann J, Qua dt-Hallman A, Mahafee WF, Kloepper JW. 1997. Bacterial endophytes in agricultural crops. Can J Microbiol. 43:895914. DOI: http://dx.doi.org/10.1139/m97-131.

Nancy PC, Luis EP, Fritz E, Franklin ER, Richard S. 2009. Combining endophytic fungi and bacteria for the biocontrol of Radopholus similis (Cobb) Thorne and for effects on plant growth. Sci Hort.122:472-478. DOI: http://dx.doi.org/10.1139/m97-131.

Nassar AH, El-Tarabily KA, Sivasithamparam K. 2005. Promotion of plant growth by an auxin-producing isolate of the yeast Williopsis saturnus endophytic in maize (Zea mays L.) roots. Biol Fertil Soils. 42:97-108. DOI: http://dx.doi.org/ 10.1007/s00374-005-0008-y.

Niere B, Gold CS, Coyne D. 2004. Can fungal endophytes control soilborne pests in banana?. Bull OILB/SROP. 27:203-209.

Obura BO. 2010. Root endophytic fungi of tomato and their role as biocontol agents of root-knot nematodes Meloidogyne incognita (Kofoid and White) Chitwood and growth promotion in tomato plants (Lycopersicon asculentum Mill.). [tesis]. Bogor (ID): Institut Pertanian Bogor.

Paparu P, Dubois T, Gold CS, Adipala E, Niere BI, Coyne D. 2004. Inoculation, colonization and distribution of fungal endophytes in Musa tissue culture plants. Uganda J Agric Sci. 9:583-589.

Pocasangre LE, Sikora RA, Vilich V, Schuster RP. 2000. Encuesta sobre los hongos endofi'ticos del banano de Ame' rica Central y el cribado para el control biolo' gico del nematodo barrenador (Radopholus similis). INFOMUSA. 9:3-5.

Sinaga RT, Lisnawita, Pinem MI. 2013. Potensi cendawan endofit dalam mengendalikan Fusarium oxysporum f.sp. cubense dan nematode Radopholus similis Cobb. pada tanaman pisang barangan (Musa paradisiaca). Agroekoteknol. 2(1):362-372.

Tan RX, Zou WX. 2001. Endophytes: a rich source of functional metabolites. Nat Product Reports. 18:448-459. DOI: http:// dx.doi.org/10.1039/b100918o.

Vuylsteke D. 1998. Shoot-tip culture for the propagation conservation and distribution of Musa germplasm. Ibadan (NE): International Institute of Tropical Agriculture.

Yan Xiao-ning, Sikora RA, Zheng Jingwu. 2011. Potential use of cucumber (Cucumis sativus L.) endophytic fungi as seed treatment agents against rootknot nematode Meloidogyne incognita. J Zhejiang Univ Sci B. 12(3):219-225. DOI: http://dx.doi.org/10.1631/jzus.B1000165. 